1 Instituto René Rachou (IRR) - Fiocruz Minas

- Belo Horizonte (MG)

Brasil.

marcela_lima5@hotmail.

com

2 Universidade Federal de Ouro Preto (Ufop) - Ouro Preto (MG), Brasil.

\section{Territory and deterritorialization: the social suffering by environmental disaster resulting from the breaking of mining dams}

\author{
Território e desterritorialização: o sofrimento social por desastre \\ ambiental decorrente do rompimento de barragens de mineração
}

Marcela Alves de Lima Santos', Núncio Antônio Araújo Sol2 2 , Celina Maria Modena'

DOI: 10.1590/0103-11042020E218I

\begin{abstract}
In Mariana, state of Minas Gerais, after the Fundão Dam rupture, families went through a process of deterritorialization, in which they were moved from rural to urban areas. Thus, the aim of the study was to understand the process of deterritorialization in this context, the implications of the loss of this social locus for the lives of those affected and for the construction of public health responses and policies. A qualitative research was conducted from 2016 to 2018 in the city of Mariana, using participant observation techniques and interviews with affected people. The interviews were analyzed based on Content Analysis and the discussion was guided by the theoretical framework of the concepts of territory, deterritorialization, and social suffering. In the observation and reports of the participants, the symbolic relationship with their place of origin is remarkable, translated in the form of bonds and belonging. Losses, in their different dimensions, impact life from grief to social suffering. Until the resettlement is achieved, it is necessary that the interpretations of this new living are not pathologized so that people can be aware of this process and be the protagonists of their choices.
\end{abstract}

KEYWORDS Public health. Disasters. Sociocultural territory.

RESUMO Em Mariana, estado de Minas Gerais, após o Rompimento da Barragem de Fundão, famílias passaram por processo de desterritorialização, em que foram deslocadas da área rural para a área urbana. Assim, o objetivo do estudo foi compreender o processo de desterritorialização nesse contexto, as implicações da perda desse locus social para a vida dos atingidos e para a construção de respostas e políticas públicas de saúde. Foi realizada pesquisa qualitativa no período de 2016 a 2018 no município de Mariana, utilizando as técnicas de observação participante e entrevistas com pessoas atingidas. As entrevistas foram analisadas a partir da Análise de Conteúdo, e a discussão foi orientada pelo referencial teórico dos conceitos de território, desterritorialização e sofrimento social. Na observação e nos relatos dos participantes, é marcante a relação simbólica com seu lugar de origem, traduzidos na forma de vínculos e pertencimento. As perdas, em suas diferentes dimensões, impactam a vida desde o luto até o sofrimento social. Até o reassentamento, é necessário que as interpretações desse novo viver não sejam patologizadas para que as pessoas consigam estar conscientes desse processo e serem protagonistas das escolhas.

PALAVRAS-CHAVE Saúde pública. Desastres. Território sociocultural. 


\section{Introduction}

The state of Minas Gerais, historically marked by mining development, has become a scenario for the rupture of some dams in recent years. Previous rupture episodes had already occurred, such as that in the municipalities of Itabirito in 1986 and Cataguases in 2003'. Despite these previous facts, the disasters of the Fundão Dam rupture, which is the responsibility of the company Samarco Mineração S.A. and its maintainers Vale S.A. and BHP Billiton, in the municipality of Mariana, in November 2015; and the Disruption of Dam I of the Córrego do Feijão mine, owned by Vale S.A., in the municipality of Brumadinho, in January 2019, which bring visibility to the theme and to the different types of damage and suffering caused to the affected population. It should be clarified that the concept of disaster is related to a serious interruption of the operation of a community or society, which causes great losses and impacts and which exceeds the capacity of the affected community or society to deal with the situation counting on its own resources ${ }^{2}$. After Brumadinho, other municipalities such as Barão de Cocais and Nova Lima (Macacos) started to deal with the risk of dam ruptures, which were silenced until then.

In Mariana, about 300 families were displaced from the rural area, mainly from the communities of Bento Rodrigues and Paracatu de Baixo, to the urban area ${ }^{3}$. In 2019, the same happened in Brumadinho, despite the differing proportions. Faced with the risk of new dam ruptures, other communities in the state experienced the situation of being abruptly removed from the place where they used to live ${ }^{4}$, leaving properties, stories, and social and cultural relations behind.

Among the experiences in common, these communities from different municipalities go through a process of deterritorialization and are obliged to live elsewhere. As conceptualized by Deleuze ${ }^{5(4)}$,

[...] there is no territory without an exit vector from the territory and there is no exit from the territory, that is, deterritorialization, without, at the same time, an effort to reterritorialize elsewhere.

The territory is understood not only as a geographical space, but also as something that has an existential value

[...] it circumscribes, for each one, the field of the family and the binding, marks the distances in relation to others and protects from chaos. The intimate investment of space and time implies this delimitation, which is inseparably material and [...]affective ${ }^{6(23)}$.

The context of dam rupture is yet another example of a situation of socio-environmental injustice, in which, in view of the exposure to environmental damage from development, there is an abrupt and violent displacement of social groups ${ }^{7}$. This condition leads the groups who have completely changed their ways of life to suffering.

In this scenario, suffering of social origin ${ }^{8}$ is found in individuals who have their reality changed and are placed in a situation of deprivation. Freitas and collaborators point out the importance of understanding the consequences of these disasters in addition to the number of deaths and immediate health damage, and in the identification of new health problems and needs throughout time ${ }^{9}$. Thus, it is important to understand this condition of displacement and territorial loss and how people are affected in this process so that health policies are developed in a broader perspective.

Therefore, we seek to understand the process of deterritorialization in the context of dam rupture, the implications of the loss of this social locus for the lives of the affected people and for the construction of responses and public health policies. 


\section{Materials and Methods}

Qualitative research was carried out in the municipality of Mariana (MG), between the years of 2016 and 2018, seeking to understand the health impacts of the population affected by the Fundão Dam Rupture that occurred on November 5, 2015. This study was approved by the Research Ethics Committee (CEP) of the Instituto René Rachou (IRR) of the Oswaldo Cruz Foundation (Fiocruz) according to Opinion No. 1,578,823 / CAAE 53911916.0.0000.5091.

The city of Mariana is in the central region of Minas Gerais, approximately $110 \mathrm{~km}$ from Belo Horizonte. Also known as the Primate of Minas, it was the first capital of the state. In 2019, the city had an estimated population of 60,724 people distributed over a territorial extension of $1,194.208 \mathrm{~km}^{2}{ }^{10}$. It is a municipality that has a strong economic dependence on mining and little economic diversification.

The most affected places in this disaster were Bento Rodrigues and Paracatu de Baixo, subdistricts that were buried in the mud. Bento Rodrigues was a calm place, with forests, waterfalls and churches and had a population of approximately 600 people. Paracatu de Baixo, also a quiet rural area, had about 300 inhabitants. Both subdistricts had health units and schools, the Bento Rodrigues Municipal School and the Paracatu de Baixo Municipal School, which were also destroyed in this disaster"11.

The information shown in this article is part of this investigation process and brings elements found in the field. Analyses are presented based on participant observation carried out by the first author during these two years in health services and in community and collective spaces built by those affected in that period. The participation in the field made it possible to get closer to reality and to the daily experiences of these people. Participant observation also makes it possible to link facts to their representations by a certain group and allows the researcher to relativize their social space and learn to be in another person's shoes ${ }^{\mathbf{1 2}}$.

Interviews were also conducted with people affected in the end of 2017 in Mariana, to understand the meaning of the changes due to the disaster, the deterritorialization and its consequences for the daily life and health of this population. The interviews were recorded and transcribed, after a free and informed consent process. Before submission, the participants were contacted again to authorize or not the use of the interview and the submission of the text. After a meeting explaining the purpose of the study, a copy of the transcribed interview was given to them, so that they could remember what the content was and remove or add any information. After this process, the participants legitimated the use and disclosure in this scientific article, safeguarding anonymity.

For this investigation, the content analysis technique ${ }^{13}$ was used, seeking to understand the meanings attributed by the participants to this change in the reality of life, the need to adapt to a new territory and the consequences of the disaster for the health of the affected population.

Thus, based on the experience in Mariana and on the analysis of the narratives of the affected people, the purpose is to point out the meanings attributed to the phenomenon and contribute with possibilities of actions for the new scenarios in the state of Minas Gerais and that may also appear in other places.

\section{Results and discussion}

In Mariana, after the Samarco disaster, families moved from rural to urban areas. The same movement can also be identified in Brumadinho, after the rupture of Dam I of the Córrego do Feijão mine, and in communities such as in the municipality of Barão de Cocais, with the risk of rupture of another dam of Vale S.A. In all these cases, interventions by people and public and private institutions to support these groups were indispensable. 
Considering the relevance of social and environmental determinants for the healthdisease process, it is possible to see that the consequences for health go far beyond the moment of disaster and displacement of families. It is necessary to highlight that disasters are not limited to the catastrophic event and can intensify the crisis and social suffering according to the institutional responses that are given ${ }^{\mathbf{1 4}}$. Given this scenario, we have to understand the uses that are made in these different places and how these environmental changes bring new concerns in the health area.

The imposed changes mark the history of these people who are forced to adapt to a new place, with new standards and lifestyles. The proximity to the reality of those affected also shows that, with the dam rupture and the abrupt withdrawal of communities from the places where they live, bonds are broken and memories fade.

Thus, it is necessary to understand the territory beyond a perspective of geographic and static delimitation, which also permeated by all its social, historical and affective relationships. As defined by Guattari and Rolnik ${ }^{15(323)}$ :

The territory can be related to a space where someone lived, and a system within which someone feels 'at home'. Territory is synonymous with appropriation, with subjectivity closed on itself. It is the set of projects and representations that will lead, pragmatically, to a whole series of behaviors, investments, in social, cultural, aesthetic and cognitive times and spaces.

Milton Santos ${ }^{16}$ brought important contributions to Public Health, presenting the territory as a dynamic, living object, full of interrelations, proposing the detailing of the territory's reciprocal influences with society, its essential role on the life of the individual and the social body.

Thus, the territory is understood as a space in which life stories happen and are modified based on political, economic and environmental processes. Dam rupture has led to scenarios of ruptures in these life cycles, demanding adaptation to a new territory, as well as participation in other community instances and political negotiation and contact with new institutions.

Haesbaert ${ }^{17}$ presents a conception of territory from three aspects: the legal-political one, in which the territory is understood as a space in which a certain power is exercised; the culturalist one, which prioritizes the understanding of the symbolic-cultural dimension; and the economic one, which emphasizes the social dimension of economic relations and the clash between social classes and the capital-labor relationship.

In the reports of those affected, the symbolic relationship established with this place is evident, since most people have lived in the same place since they were born and have chosen to start their families there. There is a link between the residents of the districts of Bento Rodrigues and Paracatu de Baixo and how life was built in a simple and quiet way, as exemplified in the excerpt below:

When we lived there... Everyone lived in a quiet place. Everyone had their little houses. Those who didn't have their own houses had to pay their rent, but they were local people. If a stranger would come to live nearby, everyone knew they were coming, and everybody would become friends. It was a nice place. Everyone knew each other.

Insecurity appears as a landmark in this new territory where relationships of trust are rarer. As shown in the statement above, in small rural areas, everyone knew each other; and the social support network was larger and more strengthened. With the displacement to the urban area and the distance between the houses, community bonds break. In addition, communities begin to live in an environment of greater exposure to various types of violence. Thus, this population also goes through a process of vulnerability ${ }^{6}$.

In this scenario, we find losses that lead us 
to an expected grieving process. In the disaster in Mariana, there were 19 deaths that meant significant losses to families and communities. However, in this article, the discussion is focused on the mourning and suffering of social and symbolic origin. This context brings relations of deprivation and losses that can be observed in several dimensions. In the speech below, it is possible to identify the distance and separation that go beyond the spatial or geographical limit and determine a new conformation of social relations.

It was a ridiculously small community. So, each one went to a different place, or neighborhood. And the neighborhood becomes distant, it's a small town, but it becomes distant. The mother stays here, and the daughter goes to another place. So, they are separated. There were people we saw every day, sometimes twice a day, and today we don't even get see them for a week.

As in other migratory processes in a period of globalization, economic and political interests are placed above the rights and needs of the population? ${ }^{7}$. We deal with people who have been displaced involuntarily, excluded from a place without a choice. Facing this impossibility, the adaptation to a new territory begins. The affected people went through a process of recognition of the city's urban area and had to build another social reorganization.

Thus, we found a population that is going through a deterritorialization process, which leads to the need for a new territorialization,

[...] 'reterritorialization', which leads to the controversial theme of the 'new land', the future land always to be built, against the promised or ancestral land, $[\ldots]^{\mathbf{5 ( 2 3 )}}$.

By understanding the territory in its cultural dimension, deterritorialization is seen from the process of uprooting and weakening territorial identities ${ }^{17}$. Thus, what happens is the construction of a process of social exclusion and loss of autonomy of these social groups.
When thinking about the abrupt withdrawal of these people, it is possible to relate something that is considered essential and that must be fulfilled immediately. In this case, it is a condition of leaving your history and all your material and non-material goods to continue to move on. In the interviews, people who experienced the feeling of close death are grateful for their lives: "But it was not easy at all. And today we must thank for being alive, for being here. But it is not easy for us to live in a place that is not ours".

We see that they feel grateful, even with all the pain inside. It is as if you were not allowed to complain, externalize, or say that you are not well, since you have the possibility of being alive. The sadness of having lost everything and the lack of identification with this new condition are mixed with the recognition that something worse could have happened.

And then life is different, you've already moved, you've been through a complicated situation. You lost everything. And you come to a place that is not your home. And it is an apartment and we have to adapt to the place. But everyone is grateful, and at the same time I thank God for being here.

The dialectic between life and death appears frequently in the interviewees' discourse. As stated above, life is different now; and then new things need to be built. Even in face of the concreteness of life that presents itself, death is found on the social aspect. Social death reveals a paradox regarding how the biological and the social merge, it occurs when certain losses of functions result in interdiction, in the sense that there is a disruption of the roles played by the individual in a certain group ${ }^{18}$.

Santos ${ }^{19(16)}$ points out that it is the use of territory that characterizes it as an object of social analysis and considers that "the territory used are objects and actions, synonymous with human spaces, inhabited spaces". The contact with the people affected shows how this relationship with the territory is built and how people seek to find themselves in this new 
place where the relationship of belonging does not exist. In the speeches, we identified that people recognize themselves as tenants in the urban area of Mariana, which, until then, was a territory used only to solve problems, go to a medical appointment or to the bank.

It's like someone else's home. For example, I feel that way, it's someone else's home and they can arrive at any time. I feel this way here. I am different. And that is what everyone expects, everyone is anxious because there is a scheduled date, but everyone wonders if that is really going to happen.

Shortly after the Fundão Dam rupture, the affected families were taken to a gymnasium in Mariana and, on the next day, to hotels and inns in the city ${ }^{2}$. In the month following the disaster, they began to be lodged in rented houses ${ }^{20}$. Despite living in the homes of family or friends, and not living in a collective shelter, people report feeling like they are tenants. Thus, we see that the physical space alone does not constitute the identity and the feeling of belonging to that place and how the territory is built from elements and feelings different from those that constitute it and determine its use. As conceptualized by Milton Santos 21(96),

a territory is not just the result of the superposition of a set of natural systems and a set of systems of things created by humans. The territory is the ground and the population, that is, it is an identity, the fact and the feeling of belonging to what belongs to us. Territory is the basis of work, residence, material and spiritual exchanges and life, on which it influences. When talking about territory, it is necessary, therefore, to understand that we are talking about a territory that is used by a given population.

It is also possible to identify that these people did not have emotional bonds in this new place. Thus, we can signal a non-territory, since the territory loses its sense of agglutinating identities, and people participate less in spatial and identity references ${ }^{17}$.
Between the time of the disaster and the end of the resettlement, there is a wait for a new place. When we finished this article, there was not a single house built, which means that people have been waiting for approximately four years. The reports exemplify the trajectory in this recognition, in which, between one physical space and another, people are looking for a new meaning of territories and memories.

Men usually say more: oh, I have nothing to do. I ride here and ride there, I go from one park to the other. So, I go out and sit there with a colleague, I don't know him. And there are already some meeting spots in Bento and Paracatu, as well as in other communities, and so time goes by, as they say, until this anxiety ends.

In the dynamics of adapting to this new territory, many people lost work, leisure and subsistence activities. As highlighted in the statement above, it is common to find men complaining about idleness. From that point on, some spots in the city, such as the Convention Center, stood out as a possibility of promoting meetings for these communities. As we walk and talk in the city, time seems to pass, and the long-awaited moment of a new territory, which they call "Novo Bento" or "Nova Paracatu", is expected to arrive soon.

The report a feeling of "anxiety", another way of presenting suffering. At this point, it is important to observe how the psychological symptom appears and needs to be well interpreted and sized to avoid actions in the health field that have an individualizing focus. As Weintraub and collaborators ${ }^{22}$ emphasize, mental health needs to be thought in "multiple ways, by analyzing the different meanings attributed in a singular and collective way to the event".

Anxiety is reported within a process of loss and wait for something that is greatly desired, but which no one knows whether it will come true. 
It is possible to deal with it, but I don't know how long we can take it. And then others say: 'will I stand until the expected date of return?' And others have this fear 'will the buildings actually be ready on this date?' And some people are also concerned about their adaptation to this place. But there is a difference, it is my home. But how will I adapt to the place?

There is a social condition in this context that generates suffering. Much of the deterritorialization processes are related to political and socioeconomic aspects. In the case of the dam rupture, there are interests and power relations that stand out from the desires and wishes of certain populations, placing them in a vulnerable condition. When they leave the territory where they have written their stories and built, they are left with a condition of little independence and autonomy and rupture of their social networks.

Moreover, they experienced the loss of some references and social roles. Those who liked to plant no longer had their own backyard or vacant lot in the neighborhood. Those who liked to breed animals had no animals or space. Those who used to take much of their fresh produce from their own land needed to learn how to go to the supermarket and buy products that have a different quality. Some elderly had never bought an egg before because they had always kept chickens at home.

The 40th edition of the 'Jornal A Sirene'23, published on July 2019, a newspaper designed to give voice to those affected, also shows how traditions were lost and how communities organize themselves to resist and sustain some of these habits. The edition shows some residents' reports about the Santo Antonio's festival, a traditional celebration of the patron saint of Paracatu that they strive to keep alive and not only preserved in memory. The resident's speech in the excerpt below exemplifies some of these changes for the community.

Today we went there and everything is fast, everything has to be timed. When we lived there, it was quite different because we organized all the space. The people who danced the 'quadrilha', the typical dance of the festival, were all characterized. It was incredibly beautiful and nice. There used to be a fire, shows, stands, and the street was well-decorated. Now, we no longer have the time to organize, to invite many people 23(15).

Thus, new ways of life are placed for these populations that become vulnerable and inserted in a scenario of greater social inequality. Here, vulnerability is understood as a process, which includes the historicity of the facts and the rights that were removed from these social groups ${ }^{24}$.

Thus, it is necessary to consider that there is an affected population that is placed in a condition of health inequity. So, one has to be aware of social factors in a context of so many losses, so that health issues are not reduced to diagnoses and prescriptions, culminating in processes of pathologization and medicalization ${ }^{20}$.

If we understand that the notion of trauma still acts as an operator of mental health care produced in a disaster situation ${ }^{\mathbf{2 2}}$, there may be a tendency for health professionals (doctors in particular) to reduce the suffering of these people to a number of the International Classification of Diseases (ICD), which can be solved only with the use of an antidepressant or mood modulator. In this context, diagnoses of post-traumatic stress disorder and depression are poorly prepared, as the context of illness is disregarded. In addition, medicalization, understood as a prescription aimed at suppressing symptoms, interferes with the capacity of those affected by the disaster to understand all the motivation and causes of their suffering, making it difficult to participate in instances of struggle for rights and the process of reterritorialization.

Amid anxiety, fear and strangeness, dreams are being dreamt. The desire to have their places back persists. At the same time, the interviews show that those affected also understand that 
this is a new time and a new place. When interviewed about how she would like the "Novo Bento' to be, one of those affected answers:

I hope people continue with the same friendships, because I think that will change a lot too. People's minds will not be the same when we come back. People will, but their minds won't. And I hope that everyone feels how nice it is to live there, despite being a new place. But we expect everything is smooth and we think more about this issue of adaptation, until I can say like this: this is my home. This is my street. This is our Bento. And that happens too in the other communities. But it will also have an impact at the beginning. It's all new again.

It is possible to perceive in the narratives that, while resettlement does not happen, it is necessary to continue life. Despite some projects that were interrupted and insecurity regarding the future, other relationships and bonds were also built in the urban area of Mariana. Then, once again, there is a future scenario of deterritorialization and reterritorialization. As pointed out by the victim, "it's all new again". And, once again, with this change, new analyses and interpretations need to be carried out to understand the social determinants involved and their consequences for the planning and elaboration of health actions.

\section{Final considerations}

Deterritorialization has been a frequent consequence of disasters involving the dam ruptures in Minas Gerais. With the forced displacement, people lose their memories, identifications, and social and community bonds. Thus, in addition to the deaths recorded in these disasters, there is a social death from the loss of elements and roles that constitute the life story of these people.

In this context, life needs change too. Losses, in their different dimensions, impact the lives of those affected and change the existence and/or direction of their projects. Thus, they have consequences for their health condition. Therefore, it is important that this expanded understanding of the social determinants involved be carried out to develop health care actions compatible with the real demands of the affected population, whether at the level of assistance or surveillance.

At this moment, when resettlement is still highly expected, it is necessary that the interpretations of this new life are not pathologized so that people are able to be aware of this process and so that they are also protagonists of the choices in the spaces of social participation.

\section{Collaborators}

Santos MAL (0000-0002-7579-8067)*, Sol NAA (0000-0002-7799-0458)* and Modena CM (0000-0001-5035-3427)* also contributed to the preparation of the manuscript. 


\section{References}

1. Lagoa T. Pelo menos 94 pessoas morreram após rompimento de barragens em MG [internet]. Jornal O Tempo. 2019 jan 28. [acesso em 2019 jul 30]. Disponível em: https://www.otempo.com.br/cidades/pelo-menos-94-pessoas-morreram-apos-rompimento-de-barragens-em-mg-1.2128094.

2. United Nations International Strategy for Disaster Reduction. Terminology on Disaster Risk Reduction [internet]. Geneva; Switzerland: UNISDR; 2009. [acesso em 2019 set 18] Disponível em: https://www.unisdr. org/files/7817_UNISDRTerminologyEnglish.pdf.

3. Santos MAL, Rossi SR. A construção do cuidado psicossocial aos atingidos do desastre de Mariana (MG): um relato de experiência. In: Sant'anna Filho O, Lopes DC. O psicólogo na redução dos riscos de desastres: teoria e prática. São Paulo: Hogrefe Cetepp; 2017. p. 185-196.

4. Trajano H, Leocádio T. Barragens da Vale em Macacos e Ouro Preto entram em alerta máximo para risco de rompimento [internet]. G1. 2019 mar 27. [acesso em 2019 jul 30]. Disponível em: https://gl.globo.com/ $\mathrm{mg} /$ minas-gerais/noticia/2019/03/27/barragem-da-vale-em-macacos-entra-em-alerta-maximo-para-risco-de-rompimento-e-sirenes-serao-acionadas. ghtml.

5. Deleuze G. O abecedário de Gilles Deleuze [internet]. 1989. [acesso em 2019 jul 30]. Disponível em: http://stoa.usp.br/prodsubjeduc/files/262/1015/ Abecedario+G.+Deleuze.pdf.

6. Zourabichvili F. O Vocabulário de Deleuze. Rio de Janeiro: IFCH-Unicamp; 2004.

7. Porto MFS. Complexidade, processos de vulnerabilização e justiça ambiental: um ensaio de epistemologia política. Rev Crítica Ciênc Sociais. 2011; (93):31-58.

8. Werlang R, Mendes JMR. Sofrimento social. Serviço Soc. 2013; (116):743-68.

9. Freitas CM, Barcellos C, Asmus CIRF, et al. Da Sa- marco em Mariana à Vale em Brumadinho: desastres em barragens de mineração e Saúde Coletiva. Cad. Saúde Pública. 2019; 35(5):e00052519.

10. Instituto Brasileiro de Geografia e Estatística. Panorama Mariana [internet]. 2019. [acesso em 2019 set 20]. Disponível em: https://cidades.ibge.gov.br/brasil/mg/mariana/panorama.

11. Graça A, Camargo COSFA, Santos J. A vida antes da tragédia. In: Caldas G, organizador. Vozes e silenciamentos em Mariana: crime ou desastre ambiental? 2. ed. Campinas: BCCL; Unicamp; 2017.

12. Minayo MCS. O desafio do conhecimento: pesquisa qualitativa em saúde. 14. ed. São Paulo: Hucitec; 2014.

13. Bardin L. Análise de Conteúdo. São Paulo: Edições $70 ; 2008$.

14. Zhouri A, Valencio N, Oliveira R, et al. O desastre da Samarco e a política das afetações: classificações e ações que produzem o sofrimento social. Ciênc. Cultura. 2016; 68(3):36-40.

15. Guattari F, Rolnik S. Micropolítica: cartografias do desejo. Petrópolis: Vozes; 1986.

16. Lima EFMA, Yasui S. Territórios e sentidos: espaço, cultura, subjetividade e cuidado na atenção psicossocial. Saúde debate. 2014; 38(102):593-606.

17. Haesbaert R. Da desterritorialização à multiterritorialidade. Boletim Gaúcho Geog. 2003; (29):11-24.

18. Aredes J. Um morrer em vida: a morte social na esfera da saúde [internet]. [acesso em 2019 ago 28]. Disponível em: http://observatoriodadiversidade.org.br/ site/um-morrer-em-vida-a-morte-social-na-esfera-da-saude.

19. Santos M. O retorno do território. In: Santos M, Souza MAA, Silveira ML, organizadores. Território - globalização e fragmentação. 4. ed. São Paulo: Hucitec; Anpur; 1998. p. 15-20. 
20. Santos MAL. Eu quero minha liberdade de volta! Saúde Mental e Atenção Psicossocial junto aos Adolescentes Atingidos pelo Rompimento da Barragem de Fundão. [dissertação]. Belo Horizonte: Instituto René Rachou. Belo Horizonte; 2018. 90 p.

21. Santos M. Por uma outra globalização - do pensamento único à consciência universal. 5. ed. Rio de Janeiro: Record; 2001.

22. Weintraub ACAM, Noal DS, Vicente LN. Atuação do psicólogo em situações de desastre: reflexões a partir da práxis. Interface (Botucatu). 2015 [acesso em 2020 jun 22]; 19(53):287-298. Disponível em: https://www.scielo.br/scielo.php?pid=S1414$-32832015000200287 \&$ script=sci_abstract\&tlng=pt.

23. Jornal A Sirene. Para não esquecer: Festas Interrompidas [internet]. 2019. [acesso em 2019 set 21]. Dis- ponível em: https://issuu.com/jornalasirene/docs/ julho_2019_issuu.

24. Acselrad H. Vulnerabilidade ambiental, processos e relações [internet]. In: II Encontro Nacional de Produtores e Usuários de Informações Sociais, Econômicas e Territoriais; 2006 Aug 24. Rio de Janeiro: ABIA/ IMS-Uerj; 2006. p. 1-5. [acesso em 2020 maio 6]. Disponível em: http://www.nuredam.com.br/files/divulgacao/artigos/Vulnerabilidade\%20Ambientais\%20 Proce\%20ssos\%20Rela\%E7\%F5es\%20Henri\%20 Acselrad.pdf.

Received on 09/29/2019

Approved on 02/04/2020

Conflict of interests: non-existent

Financial support: non-existent 